\title{
Optimum Protocol for Shoot Formation in karandafi Red Sorghum (Sorghum bicolor (L.) Moench) through Somatic Embryogenesis Using Mature Embryo
}

\author{
Lateefat Bolanle Hassan*, Inuwa S. Usman, Mary D. Katung, Sanusi M. Bugaje \\ Department of Plant Science, Ahmadu Bello University, Zaria, Nigeria \\ Email: haslat2000@yahoo.com
}

Received 18 December 2013; revised 14 February 2014; accepted 4 March 2014

Copyright @ 2014 by authors and Scientific Research Publishing Inc.

This work is licensed under the Creative Commons Attribution International License (CC BY). http://creativecommons.org/licenses/by/4.0/

(c) (i) Open Access

\begin{abstract}
In this study, an optimum protocol for shoot formation through somatic embryogenesis using mature embryo explants was developed. Calli were initiated on Murashige and Skoog (MS) media supplemented with varying concentration of 2,4-Dichlorophenoxyl acetic acid (2,4-D) ranging from $1.5 \mathrm{mg} / \mathrm{l}-4.0 \mathrm{mg} / \mathrm{l}$ alone or in combination with $0.5 \mathrm{mg} / \mathrm{l}$ Kinetin (KN). Significance difference $(p<0.05)$ was observed among the different concentrations of hormone used for callus induction. The highest percentage callus formation was obtained from the media fortified with 4 $\mathrm{mg} / \mathrm{l} \mathrm{2,} \mathrm{4-D} \mathrm{for} \mathrm{mature} \mathrm{embryo} \mathrm{obtained} \mathrm{from} \mathrm{imbibed} \mathrm{seed} \mathrm{while} \mathrm{for} \mathrm{the} \mathrm{preconditioned} \mathrm{mature}$ embryo, the media supplemented with $2 \mathrm{~m} / 1$ 2,4-D + $0.5 \mathrm{mg} / \mathrm{l}$ kinetin (KN) recorded more percentage callus formation compared to what was obtained from the media supplemented with 2.5 $\mathrm{mg} / \mathrm{l2}$,4-D + $0.5 \mathrm{mg} / \mathrm{l}$. More percentage shoot formation was obtained from the media supplemented with $1 \mathrm{mg} / \mathrm{l}$ 6-benzylaminopurine (BA). Average number of shoot per callus was also more in the media fortified with $1 \mathrm{mg} / \mathrm{l} \mathrm{BA}(2.25)$ but this was not significantly different from what was obtained from the media fortified with $2 \mathrm{mg} / \mathrm{l} \mathrm{BA}+0.1 \mathrm{mg} / \mathrm{l} \mathrm{2,4-D}$ at $5 \%$ level of significance.
\end{abstract}

Keywords

Sorghum bicolor; Callus Induction; In-Vitro Regeneration

\section{Introduction}

Sorghum bicolor is an important cereal crop grown in the tropics, sub-tropic and temperate regions as well as in

*Corresponding author.

How to cite this paper: Hassan, L.B., et al. (2014) Optimum Protocol for Shoot Formation in karandafi Red Sorghum (Sorghum bicolor (L.) Moench) through Somatic Embryogenesis Using Mature Embryo. American Journal of Plant Sciences, 5, 671-675. http://dx.doi.org/10.4236/ajps.2014.55081 
poor quality soils and semi-arid regions [1]. It is the fifth most important cereal crop in the world and is the dietary staple of more than half a billion people in over 30 countries [2]. Sorghum bicolor is used as food for human consumption and feed for animals. Its use as a medicinal plant is getting prominent due to the various phyto-chemicals it contains that are used for the treatment of different ailments. Being an important crop with different uses, there is a need to breed better crops that are disease resistant and high yielding varieties. With the use of conventional breeding, many years may be required to develop an improved variety. Genetic transformation through biotechnology is an alternative method of genetic improvement which can be achieved within a short period of time. An essential step of this technique is the development of efficient protocol for plant regeneration.

Explants such as immature inflorescences, immature embryos and shoot tip have been reported by [3]. To obtain immature embryo throughout the year is not easy because sorghum flowering occurs once in its life time according to [4]. Zygotic embryos from mature seed are therefore used as explants for callus induction [5]. These explants, however, present some difficulties in regeneration [6]. The objective of the study is to optimize protocol for somatic embryogenesis and plant regeneration from mature zygotic embryos of sorghum

\section{Materials and Methods}

For the purpose of this study, seed of Karandafi (a mutant red sorghum) were collected from farmers' fields in Sokoto and Katsina States. The seeds were washed with mild detergent under running tap water and surface sterilized by dipping in $95 \%$ ethanol (v/v) for 2 minutes followed by treatment with $20 \%$ commercial bleach (containing 3.5\% Sodium hypochlorite) with few drops of tween 20 for 20 minutes. Afterwards, the seeds were rinsed three (3) times with sterile distilled water and part were soaked in distilled water and some were preconditioned on hormone free MS (Murashige and Skoog) media for 24 hours. Embryos were aseptically excised from imbibed seeds using sterilized forceps and surgical blade. The excised embryos were used for callus induction on a modified semi solid MS medium [7] supplemented with sucrose $30 \mathrm{~g} / \mathrm{L}$, different concentration of 2,4-D (1.5 - $4.0 \mathrm{mg} / \mathrm{L}, 2,4-\mathrm{D})$ with or without $0.5 \mathrm{mg} / \mathrm{L}$ Kinetin (KN). In another experiment, to evaluate the effect of preconditioning of the embryo by culture on hormone free MS media for 24hrs, preconditioned embryos were excised and culture on MS media supplemented with $2.0 \mathrm{mg} / \mathrm{l}+0.5 \mathrm{mg} / \mathrm{l} \mathrm{KN}$ or $2.5 \mathrm{mg} / \mathrm{l}$ 2,4-D) + $0.5 \mathrm{mg} / \mathrm{l}$ $\mathrm{KN}$. The $\mathrm{pH}$ of the media was adjusted to 5.8 using $0.5 \mathrm{M} \mathrm{HCl}$ and $0.5 \mathrm{M} \mathrm{NaOH}$, agar $(0.8 \%)$ was used as gelling agent and the media were heated to boiling for proper mixing. The sterilization of the media was done in an autoclave at $121^{\circ} \mathrm{C}$ for 15 minutes and media were dispensed into petri dishes. Five Embryos were cultivated in each Petri dish (11mm diameter) and five (5) petri dishes were used per treatment and two (2) petri dishes were used for preconditioned mature embryo per treatment. The cultures were incubated in the darkness for callus proliferation at $25^{\circ} \mathrm{C} \pm 2{ }^{\circ} \mathrm{C}$. Activated charcoal was used to control phenolic secretion [8]. The number of explants that formed calli and percentage callus formation were recorded. For the regeneration of the explants, the calli obtained from preconditioned mature embryo were taken to regeneration media after 2 weeks of callus induction using MS medium supplemented with 1 - 2 mg/l BA + $0.1 \mathrm{mg} / \mathrm{l}$ 2,4-D. Eight test tubes were used per treatment. Percentage shoot formation, Average number of shoots per calli for each treatment and average shoot length were recorded. The data collected were subjected to analysis of variance and the mean were separated using Duncan Multiple Range Test (DMRT).

\section{Results and Discussion}

\section{Callus Induction}

Sticking out of embryo was observed after fifth day of inoculation. The calli were initially whitish in nature and this later changed to yellowish type of calli. They became reddish type on hormone free media (Figure 1). There was significant difference in percentage callus formation among the different concentrations of hormone used at $5 \%$ level of significance. Treating the explant with $4.0 \mathrm{mg} / \mathrm{l}$ 2,4-D gave the highest callus induction frequency (60\%) followed by the media fortified with $2.0 \mathrm{mg} / \mathrm{l}$ 2,4-D combined with $0.5 \mathrm{mg} / \mathrm{l} \mathrm{KN}$ which recorded (56\%) of callus induction frequency. The least callus induction frequency was obtained from the media supplemented with $1.5 \mathrm{mg} / \mathrm{l}$ 2,4-D (0\%) (Figure 2). No callus formation was obtained on hormone free media and in the media supplemented with $0.5 \mathrm{mg} / \mathrm{l} \mathrm{KN}$ alone (0\%) (Figure 2). Across all the treatments, calli with significant phenolic excretion demonstrated slow growth and most of them were lost after 3 weeks of culture. Complete (100\%) callus induction was obtained from the media fortified with $2 \mathrm{mg} / \mathrm{l}$ 2,4-D + 0.5KN when this mature embryo was 


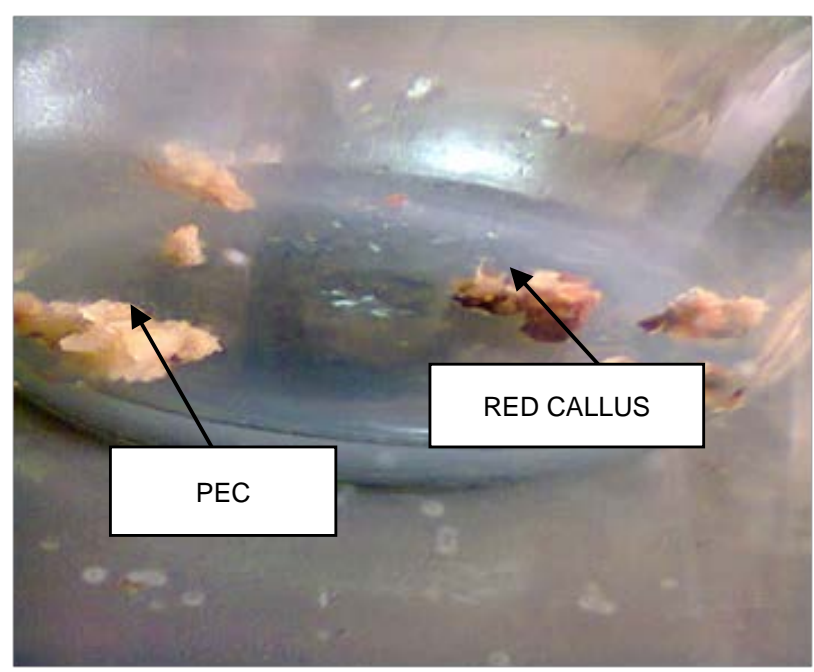

Figure 1. The calli obtained from mature embryo PEC-Potentially Embryogenic Calli; Callus obtained from mature embryo cultured.

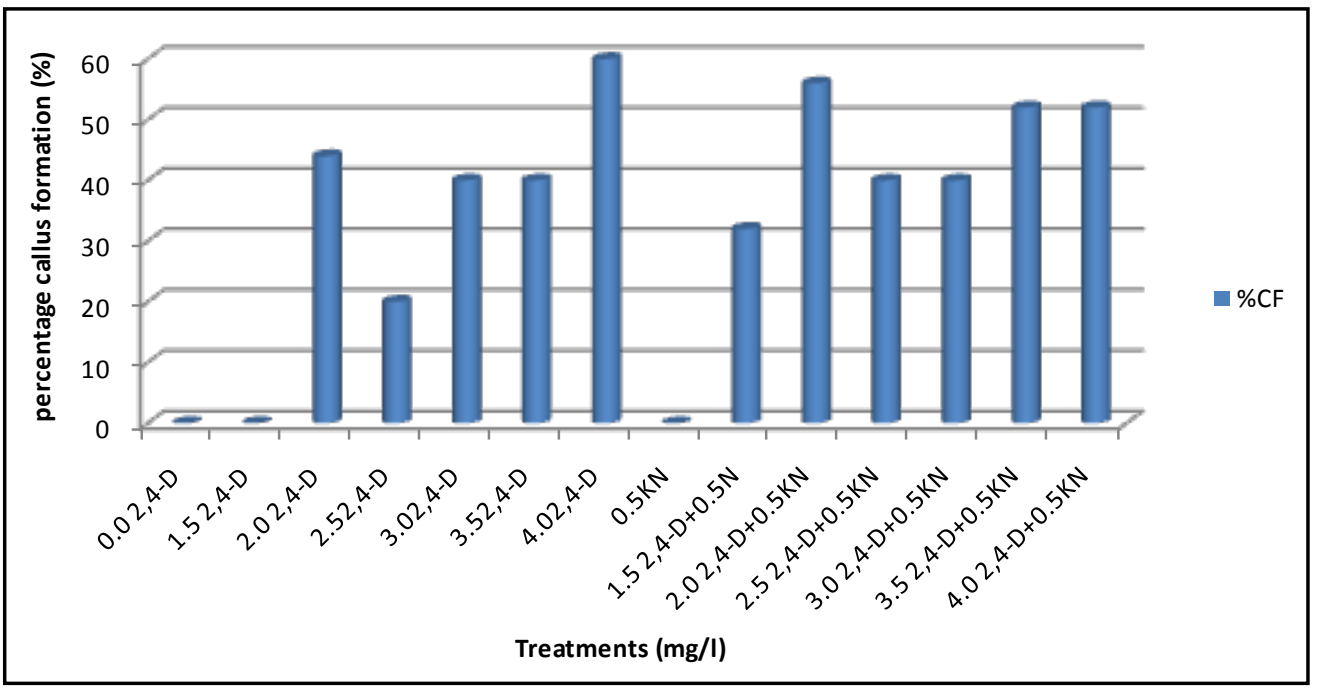

Figure 2. Effect of 2, 4-D and kinetin on callus induction using mature embryo.

preconditioned on hormone free media before inoculation (Table 1). It was observed from this study that $2 \mathrm{mg} / \mathrm{l}$ 2,4-D + 0.5KN is an optimum concentration of hormone that can be used for callus induction. This is similar to what was obtained when immature embryo was cultured by Sudhakar et al. (2008). [6] reported that the highest percentage callus formation was obtained from germinating seeds using $4 \mathrm{mg} / \mathrm{l}$ 2,4-D and the callus induction frequency was said to reduce when the concentration of 2,4-D was increased to $6 \mathrm{mg} / \mathrm{l}$. [9] reported highest callus induction frequency from immature inflorescence using $2.0 \mathrm{mg} / \mathrm{l} 2,4-\mathrm{D}+0.2 \mathrm{KN}$.

\section{Regeneration}

To induce somatic embryogenesis, calli were cultured on hormone free media and media fortified with $0.1 \mathrm{mg} / \mathrm{l}$ 2,4-D. Somatic embryo formations were observed in most of the calli transferred after three week of culture on both hormone free and media supplemented with low concentration of 2,4-D.To regenerate plantlets, developing somatic embryos were taking to regeneration media. Low level of regeneration and death of the developing embryos was observed after $3-6$ weeks of culture on regeneration media. To ensure improvement in the frequency of regeneration, whitish and compact calli obtained from preconditioned embryo were selected and cultured di- 
rectly on regeneration media fortified with different concentrations of BA. The calli turned greenish after few days of culture on regeneration media and plantlets development was observed after two weeks of culture (Figure 3). More percentage shoot formation was obtained from the media supplemented with $1 \mathrm{mg} / \mathrm{l} \mathrm{BA}$ (75\%) compared to $50 \%$ obtained from the media supplemented $2 \mathrm{mg} / \mathrm{l} \mathrm{BA}+0.1,2$, 4-D. The average number of shoot per callus was higher in the media fortified with $1 \mathrm{mg} / \mathrm{l} \mathrm{BA} \mathrm{(2.25)} \mathrm{but} \mathrm{this} \mathrm{not} \mathrm{significantly} \mathrm{differently} \mathrm{at} \mathrm{5 \%}$ level of significance with what was obtained from the media supplemented with $2 \mathrm{mg} / \mathrm{l} \mathrm{BA}+0.1 \mathrm{mg} / \mathrm{l}$ 2,4-D which recorded 1.88 (Table 2). The average shoot length was $2.26 \mathrm{~cm}$ in the media fortified with $1 \mathrm{mg} / \mathrm{l} \mathrm{BA}$ which is not significantly different from average shoot length recorded by the media supplemented with $2 \mathrm{mg} / \mathrm{l}$ BA $+0.1 \mathrm{mg} / \mathrm{l}$ 2,4-D (Table 2). Proficiency of shoot regeneration at a concentration of $2 \mathrm{mg} / \mathrm{l} \mathrm{BA}$ was reported by [8].

Table 1. Effect of 2,4-D and Kinetin on callus induction using mature embryo preconditioned on hormone free media for 24 hours.

\begin{tabular}{cccc}
\hline PGR USED & No of explants inoculated & $\begin{array}{c}\text { No of explants that } \\
\text { showed response }\end{array}$ \\
\hline $2,4 \mathrm{D}$ & KINETIN & 10 & 10 \\
2.0 & 0.5 & 10 & 4 \\
2.5 & 0.5 & Frequency of callus \\
formation (\%)
\end{tabular}

Table 2. Effect of BA alone or in combination with 2,4-D on plant regeneration.

\begin{tabular}{|c|c|c|c|c|c|c|c|}
\hline $\begin{array}{l}\text { PGR } \\
\text { USED }\end{array}$ & & $\begin{array}{l}\text { No of callus } \\
\text { inoculated }\end{array}$ & $\begin{array}{l}\text { No of explants } \\
\text { with response }\end{array}$ & $\begin{array}{l}\text { Percentage shoots } \\
\text { formation (\%) }\end{array}$ & $\begin{array}{l}\text { Total number of } \\
\text { shoot/treatment }\end{array}$ & $\begin{array}{l}\text { Average number } \\
\text { of shoot/callus }\end{array}$ & $\begin{array}{l}\text { Average shoot } \\
\text { length }(\mathrm{cm})\end{array}$ \\
\hline BA (mg/l) & 2,4-D (mg/l) & & & & & & \\
\hline I & 0 & 8 & 6 & 75 & 18 & $2.25 a$ & $2.26 \mathrm{a}$ \\
\hline 2 & 0.1 & 8 & 4 & 50 & 15 & 1.88a & 1.48a \\
\hline
\end{tabular}

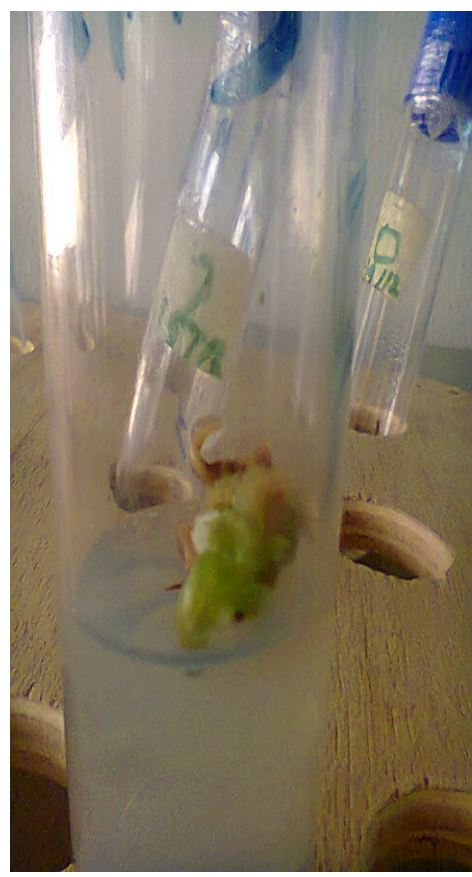

(a)

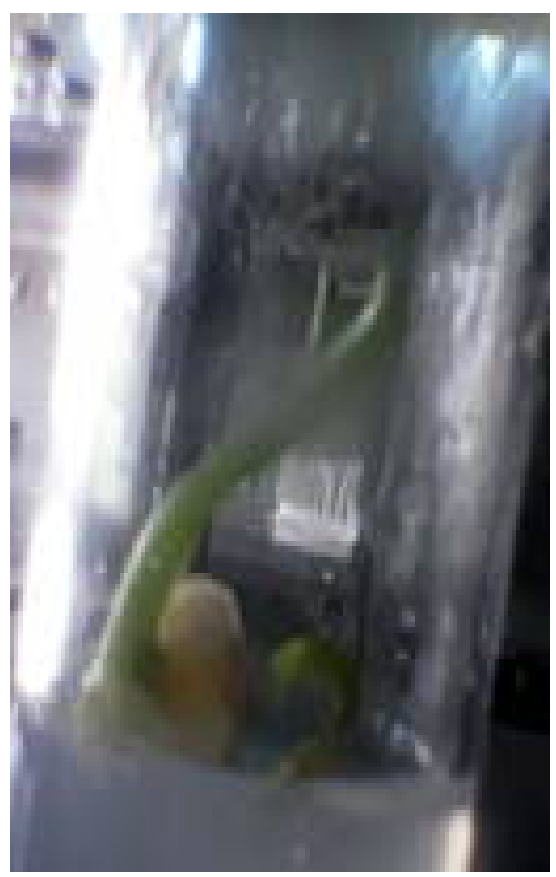

(b)

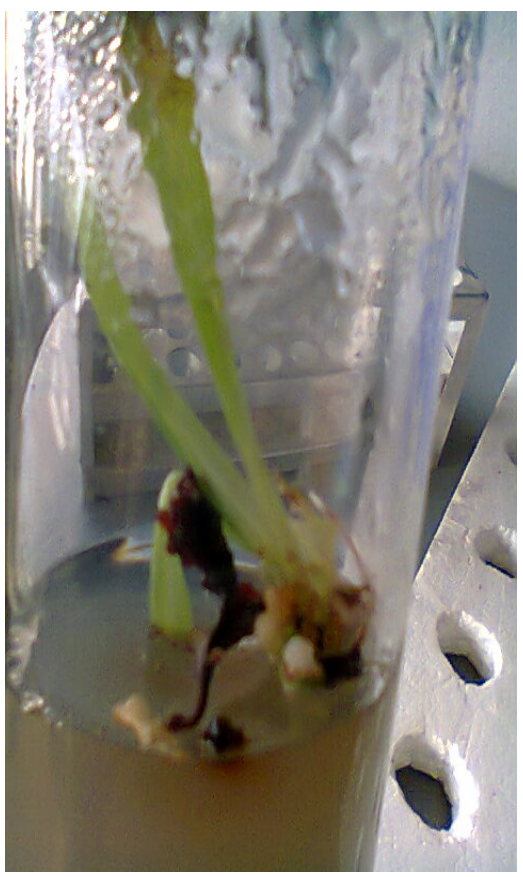

(c)

Figure 3. Plant regeneration through somatic embryogenesis. (a) shoots initiation stage. (b) shoots multiplication stage. (c) shoots elongation stage. 
Better shoot regeneration using $2.5 \mathrm{mg} / \mathrm{l} \mathrm{TDZ}$ plus $1.0 \mathrm{mg} / \mathrm{l} \mathrm{BA}$ and $0.5 \mathrm{mg} / \mathrm{l} \mathrm{IAA}$ was reported by [4]. [10] reported multiple shoot formation using $2 \mathrm{mg} / \mathrm{l} \mathrm{BA}+\mathrm{TDZ}$ (Thidiazuron). [11] reported maximum number of shoot formation in sorghum using $13.3 \mathrm{uM} \mathrm{BA}$ and $2.3 \mathrm{uM}$ 2,4-D. Research had shown that the major problems of using tissue culture technique for genetic improvement in sorghum were due to production of phenolic compounds, low regeneration frequency of mature seeds and longer time required to obtain immature embryo. With the efficient method of regeneration, improved crop variety could be made available to farmers using tissue culture technique. So in this study, it was observed that better response was obtained when the mature seeds were preconditioned on hormone free media before it was taken to callus induction media. In conclusion, a protocol for shoot formation had been optimized using mature embryo. This showed that there was a possibility of improving regeneration from mature embryo by preconditioning the mature seed on hormone free media before inoculation.

\section{Acknowledgements}

My word of appreciation goes to Dr. I.S. Usman, the Head of Plant Science Department, ABU, Zaria, the technologists in the biotechnology laboratory and Institute for Agricultural Research (IAR) for their financial support throughout the course of this research work.

\section{References}

[1] Grassi, G. (2001) Sweet sorghum lament network. Munich, 10-25.

[2] ICRISAT (2010) http//test/icrisat.org/sorghum/sorghum.htm

[3] Indra, A.P. and Krishnaveni, S. (2009) Effect of Hormones, Explants and Genotypes on in Vitro Culturing of Sorghum. Journal of Biochemistry Technology, 1, 96-103.

[4] Sudhakararao, P. (2011) Leaf Discs as a Source Material for Plant Tissue Culture Studies of Sorghum bicolor (L.) Moench. Nortulae Scientia Biologicae, 3, 70-78.

[5] Liming, Z., Shujun, L. and Songquan, S. (2010) Optimization of Callus Induction and Plant Regeneration from Germinating Seeds of Sweet Sorghum (Sorghum bicolor (L.) Moench). African Journal of Biotechnology, 9, 2367-2374.

[6] Liming, Z., Shujun, L. and Songquan, S. (2010) Optimization of Callus Induction and Plant Regeneration from Germinating Seeds of Sweet Sorghum (Sorghum bicolor (L.) Moench). African Journal of Biotechnology, 9, 2367-2374.

[7] Murashige, T. and Skoog, F. (1962) A Revised Medium for Rapid Growth and Bioassays with Tobacco Tissue Cultures. Physiology of Plantarum, 15, 473-497. http://dx.doi.org/10.1111/j.1399-3054.1962.tb08052.x

[8] Sudhakhar, P., Sarada, M.N. and Ramana, T. (2008) Plant Tissue Culture Studies in Sorghum bicolor: Immature Embryo Explants as the Source Material. International Journal of plant Production, 2, 1-14.

[9] Manjula, S.M., Kuruvinasetti, M.S. and Harti, C.C. (2000) Regeneration Establishment and Evaluation of somaclones in Sorghum Bicolor (L.) Moench. Euphytical, 115, 173-180. http://dx.doi.org/10.1023/A:1004010315991

[10] Pola, S., Mani, N.S. and Ramana, T. (2009) Long Term Maintenance of Callus Cultures from Immature Embryo of Sorghum bicolor. World Journal of Agricultural Sciences, 5, 415-421.

[11] Baskaran, B., Rajeswari, R. and Jayabalan, N. (2006) Development of an in Vitro Regeneration System in Sorghum (Sorghum bicolor (L.) Moench Using Root Transverse Thin Cell Layers (tTLCs). Turkish Journal of Botany, 30, 1-9. 